\title{
GEOMETRIC MORPHOMETRY SUPPORTS A TAXONOMIC REVISION OF THE MEDITERRANEAN BATHYPOREIA GUILLIAMSONIANA (SPENCE BATE, 1857) (AMPHIPODA, BATHYPOREIIDAE)
}

BY

\author{
TIZIANA CURATOLO ${ }^{1}$ ), CLAUDIA CALVARUSO ${ }^{1}$ ), BELLA S. GALIL ${ }^{2}$ ) and \\ SABRINA LO BRUTTO ${ }^{1,3}$ ) \\ 1) Dipartimento di Scienze e Tecnologie Biologiche Chimiche e Farmaceutiche (STEBICEF), \\ Sezione Biologia Animale, University of Palermo, via Archirafi 18, I-90123, Palermo, Italy \\ ${ }^{2}$ ) National Institute of Oceanography, Israel Oceanographic \& Limnological Research, \\ P.O. Box 8030, Haifa 31080, Israel
}

\begin{abstract}
Bathyporeia guilliamsoniana (Spence Bate, 1857) specimens collected in the Levantine Basin of the Mediterranean Sea displayed polymorphism in some characters. More than 100 specimens were examined and their intra-specific variation in the shape of the third epimeral plate analysed and quantified. The morphometric geometry methodology is used to assess the 'cryptic' variation in shape which may obscure identification. The results support the assignment of sunnivae and megalops to morphotypes of B. guilliamsoniana sensu d'Udekem d'Acoz \& Vader (2005).
\end{abstract}

Key words. - Bathyporeia, geometric morphometry, eastern Mediterranean

\section{RIASSUNTO}

Individui di Bathyporeia guilliamsoniana (Spence Bate, 1857), campionati nel Mediterraneo orientale, sono risultati essere di particolare interesse per il polimorfismo fortemente accentuato nella forma di alcuni caratteri. Non a caso, recentemente il genere è stato oggetto di una revisione che ha messo in luce la presenza di morfotipi, fino a quel momento considerati ascrivibili al rango di specie. Nel presente lavoro l'approccio di morfometria geometrica viene portato come esempio di metodologia utile alla individuazione di quella variazione 'criptica' che spesso influenza la corretta identificazione delle specie. Su oltre cento individui, la profondità dell'incavo nell'angolo postero-distale del terzo epimero è stata messa in relazione con la lunghezza degli individui, senza discriminare raggruppamenti. I risultati supportano le forme sunnivae e megalops morfotipi di Bathyporeia guilliamsoniana in accordo con d'Udekem d'Acoz \& Vader (2005).

Parole chiave. - Bathyporeia, morfometria geometrica, Mediterraneo orientale

\footnotetext{
3 ) Corresponding author; e-mail: sabrina.lobrutto@unipa.it 


\section{INTRODUCTION}

The presence of variation in morphological characters among individuals of widely distributed species has baffled taxonomists (e.g., Elasmopus spp., see Vader \& Krapp-Schickel, 2012; Jassa spp., see Conlan, 1990). Perceived variation leads to erection of subspecific eco-morphotypes and, occasionally, to erroneous identifications. When misidentifications occur in the framework of environmental monitoring, in which species richness determines the health of a given habitat (Borja et al., 2000), they may impact management and, thus, conservation. Therefore, tools that assist in the discrimination and delimitation of species are particularly important. Although molecular tools are used more and more for taxonomic studies (e.g., Sirna Terranova et al., 2007; Costa et al., 2009), we propose that morphological methodologies, such as geometric morphometrics, can be used for identification of eco-morphotypes. This method captures the geometry of morphological structures for use with multivariate statistical analyses (see Viscosi \& Cardini, 2011). The geometry of morphological structures is of particular interest to the fields of taxonomy, systematics, and population biology (e.g., Deidun et al., 2011).

Bellan-Santini (1989) redescribed and illustrated ten species in the genus Bathyporeia Lindström, 1855 occurring in the Mediterranean, including B. guilliamsoniana (Spence Bate, 1857), B. megalops Chevreux, 1911 and B. sunnivae BellanSantini \& Vader, 1988. Bathyporeia megalops differs from B. guilliamsoniana in having larger eyes; $B$. sunnivae differs by the absence of spines dorsally on the first urosomite, whereas B. guilliamsoniana possesses one pair of anteriorly directed setae and one pair of spines on the first urosomite. Bathyporeia megalops and $B$. sunnivae were synonymised with $B$. guilliamsoniana by d'Udekem d'Acoz $\&$ Vader (2005), who placed the three forms, guilliamsoniana, megalops and sunnivae, within B. guilliamsoniana (fig. 1). "Megalops" are considered adult males of B. guilliamsoniana with very large eyes, dorsally fused or in contact; the "forma sunnivae" seems to be limited to females and immature males (d'Udekem d'Acoz \& Vader, 2005). Further d'Udekem d'Acoz et al. (2005) noted that Bathyporeia species exhibit a wide variety of forms, related to definite anatomical characters and/or occurring in restricted geographical areas.

Within B. guilliamsoniana the postero-distal part of the third epimeral plate (Ep3) showed a variable shape of the depth of the notch formed by the posteroventral tooth, which could be more or less pronounced, or absent. Nevertheless, Bellan-Santini (1989), d'Udekem d'Acoz (2004) and d'Udekem d'Acoz \& Vader (2005) used the presence/absence of the tooth as diagnostic character in the taxonomic keys. In this study geometric morphometrics was used to quantitatively assess the variation in this character among individuals displaying the three "forms" (guilliamsoniana, megalops, and sunnivae) of B. guilliamsoniana. 


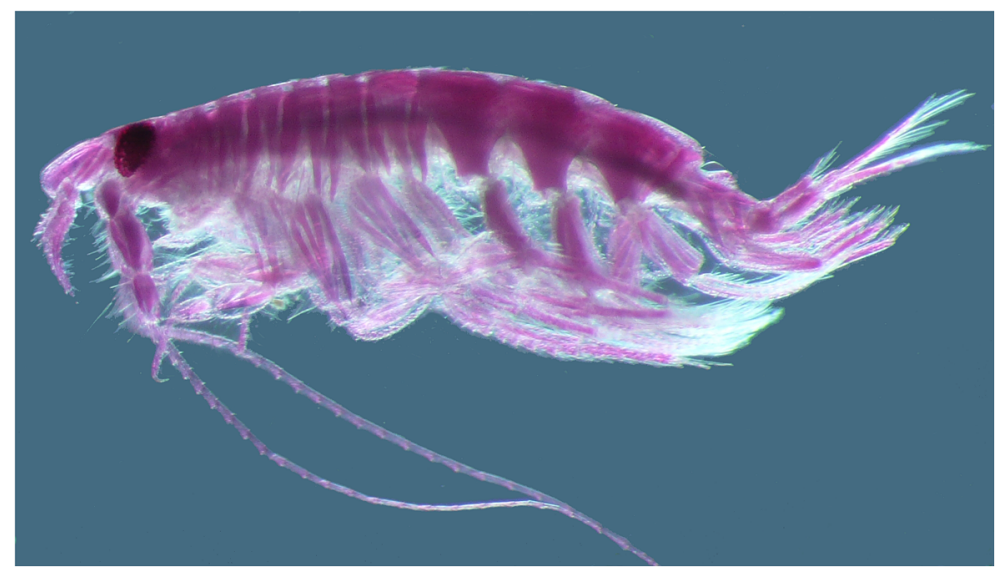

Fig. 1. Bathyporeia guilliamsoniana (Spence Bate, 1857) (adult male). This figure is published in colour in the online version of this journal, which can be accessed via http://booksandjournals. brillonline.com/content/15685403.

\section{MATERIAL AND METHODS}

Specimens of B. guilliamsoniana were collected off Ashdod, Israel, on sandy bottom (grain size between 125 and $500 \mu \mathrm{m}$ ), at depths ranging from 6 to $20 \mathrm{~m}$, in May 2010. The specimens were measured from the tip of the rostrum to the tip of the telson. Analyses were performed, comparing their geometric shape based on the information captured by the Cartesian coordinates of sets of topographically corresponding anatomical landmarks, or semi-landmarks in the case of coordinates of points on the curves (Rohlf, 1993; Adams et al., 2004; Zelditch et al., 2004; Viscosi \& Cardini, 2011).

Images were taken using a Leica D-LUX 3 LMS camera, mounted on a Leica DM 4000B microscope. The digital images were processed with MakeFan6 software (Sheets, 2003) which created a "fan shape", i.e., a graphical tool for picking out points to digitize along a curve. Fig. 2 shows how MakeFan6 placed nine semi-landmarks, using parallel lines at equal distance, and the two landmarks. The coordinates of landmarks and semi-landmarks were then digitised using tpsDIG 2 software (Rohlf, 2004), and thereafter the semi-landmarks were specified in relation to the landmarks by tpsUtil 1.45 (Rohlf, 2008).

With a landmark-based analysis, the shape can be defined as the information remaining in a figure after location, scale and orientation data are removed (Bookstein, 1991, 1996). This was performed by optimally superimposing landmark configurations, using the Generalized Procrustes Analysis (GPA), which is based on a least-squares algorithm (fig. 3) (Rohlf \& Slice, 1990). To optimize the translating, scaling and rotating of landmarks, the points are slid along the outline curve until they perfectly match the positions of corresponding points along an outline 


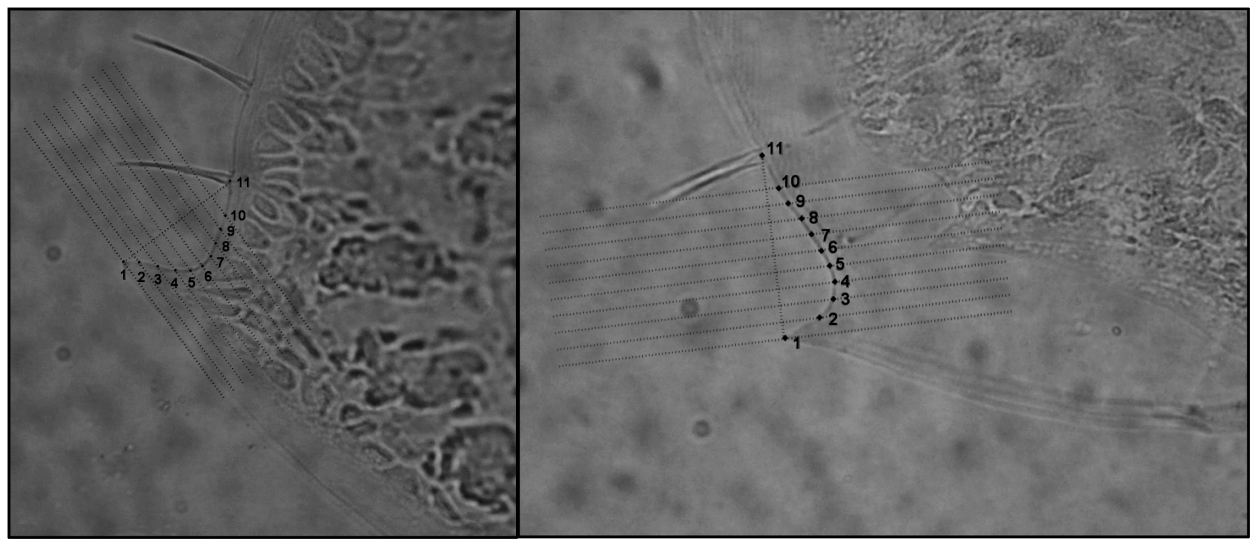

Fig. 2. The landmarks (points 1 and 11) and the semi-landmarks (points 2 to 10) were digitised onto the notch formed by the tooth in the postero-distal part of the third epimeral plate (Ep3) of Bathyporeia guilliamsoniana (Spence Bate, 1857). The images show that the landmarks were placed on the apex of the posterior tooth and at the basis of the most distal setule on the posterior margin, whereas the semi-landmarks have been placed using the parallel lines drawn using the MakeFan6 software (Sheets, 2003).

in a reference specimen (Bookstein, 1997; Bookstein et al., 2002). The perpendicular projection, or minimum Procrustes distance criterion in this study, was used to align the semi-landmarks along their respective curves. In this case, the coordi-

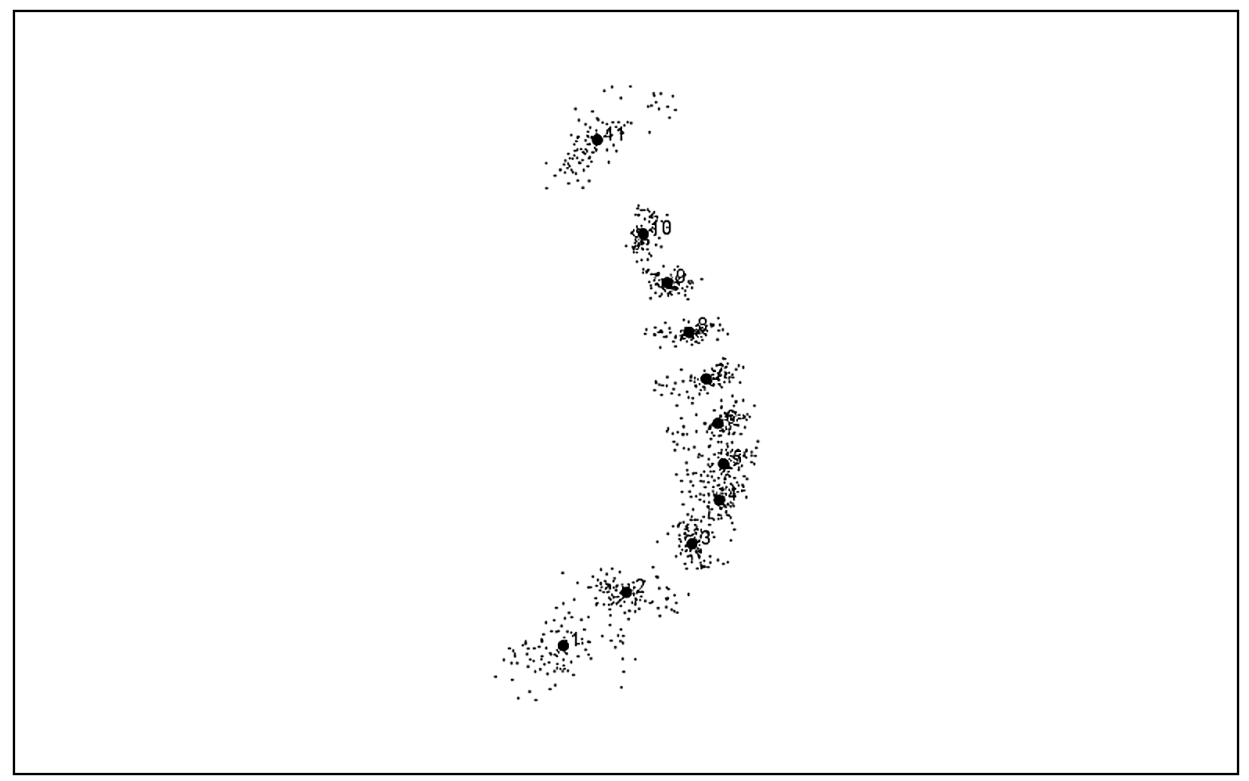

Fig. 3. A Procrustes fit of landmarks and semi-landmarks on an outline of the depth of the notch formed by the tooth in the postero-distal part of the Ep3 of Bathyporeia guilliamsoniana (Spence Bate, 1857), analysed using Generalized Procrustes Analysis (GPA). 
nates of the outlines were slid along a tangential direction, in order to minimise the Procrustes distance between the specimen and a reference (Sampson et al., 1996; Sheets et al., 2004).

An important aspect of this analysis is that the results of statistical analysis can be expressed as a deformation of each case over the mean form or reference (Bookstein, 1989, 1991; Rohlf, 1993, 1996). A Principal Components Analysis (PCA) was performed using MorphoJ 1.01 software (Klingenberg, 2011). The total variability by each principal component axis was evaluated and included in the graph of fig. 4A.

The study also examined the trend in morphological change throughout the body size of individuals. A multivariate regression analysis of the shape of the tooth of Ep3 against the total length ( $\mathrm{mm}$ ) of specimens was carried out using the principal component 1 (PC1), to determine which shape change best described allometry, using tpsRegr (Rohlf, 2005). The resulting graph was designed using Statistica 8.0 software (Statsoft, 1984-2007).

\section{RESULTS AND DISCUSSION}

In total 123 females and 36 males were collected, ranging in length from 1.5 to $4.5 \mathrm{~mm} ; 109$ epimera were analysed (39 from individuals approx. $2 \mathrm{~mm}$ in size, 59 from individuals approx. $3 \mathrm{~mm}$ in size and 11 from individuals larger than $4 \mathrm{~mm}$ ). The majority of females displayed the "forma sunnivae", i.e., "setae without spines' on the dorsal side of the first urosomite. Dorsally in contact or fused eyes were found in the largest male specimens, corresponding to the "forma megalops".

The presence of a more or less evident concavity in the postero-distal part of Ep3 was a character that manifested itself with a less pronounced tooth in the majority of females $(95 \%)$, whereas in males the tooth was either scarcely visible $(60 \%)$ or well developed (40\%).

Geometric morphometrics was used for a better understanding of the range within which the postero-distal tooth of Ep3 changed in shape and to characterise shape changes with length of individuals. The digital images of 109 epimeral plates were compared utilising PCA (fig. 4A); the thin-plate spline (a continuous curve fitted through a given set of points) deformation grids were generated to facilitate description of shape variation as it discerns the significant variations (fig. 4B).

Ninety percent of the shape variation was described in principal component 1 (PC1) through to 2 (fig. 4A). PC1, which described $74.28 \%$ of the variation, correlated significantly with individual size $\left(r^{2}=0.342, p<0.001\right)$ (fig. 5). This relationship describes a curvature of the notch of the third epimeral plate that is less deep in larger individuals, i.e., a notch varying from shape III (fig. 4B) in 


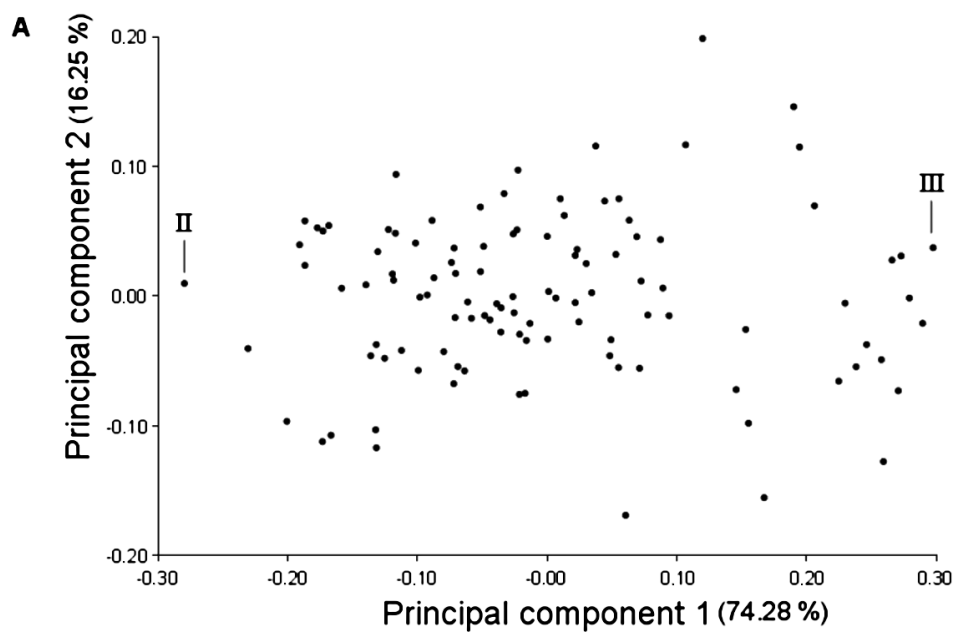

B

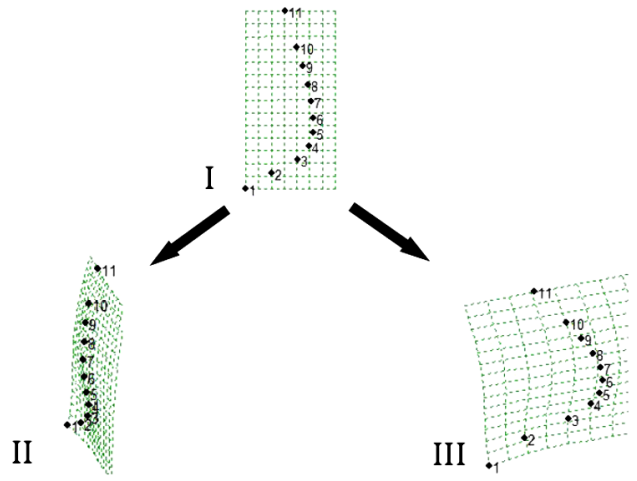

Fig. 4. A, Scores of the first two principal components of Procrustes shape coordinates for Bathyporeia guilliamsoniana (Spence Bate, 1857) individuals; B, Thin-plate spline deformation grids showing the deviation from the consensus shape I to an extreme shape 'less pronounced tooth' identified in the individual II in the graph, and to the second extreme shape 'pronounced tooth', individual III in the graph. The two endpoint shapes II and III have been chosen according to their position along the axis of the principal component 1 (PC1). This figure is published in colour in the online version of this journal, which can be accessed via http://booksandjournals.brillonline.com/ content/15685403.

smaller specimens, to shape II (fig. 4B) in larger specimens. Epimeral shape, thus, appeared to change with body size.

Epimeral shape was used as diagnostic character to distinguish between Bathyporeia species (Bellan-Santini, 1989), and the shape of the postero-ventral tooth of the Ep3 was used as a diagnostic character in the key to Mediterranean Bathyporeia species proposed by d'Udekem d'Acoz \& Vader (2005). However, d'Udekem d'Acoz \& Vader (2005) observed that the tooth in the postero-distal part of the third epimeral plate is less pronounced in B. guilliamsoniana adult males. 


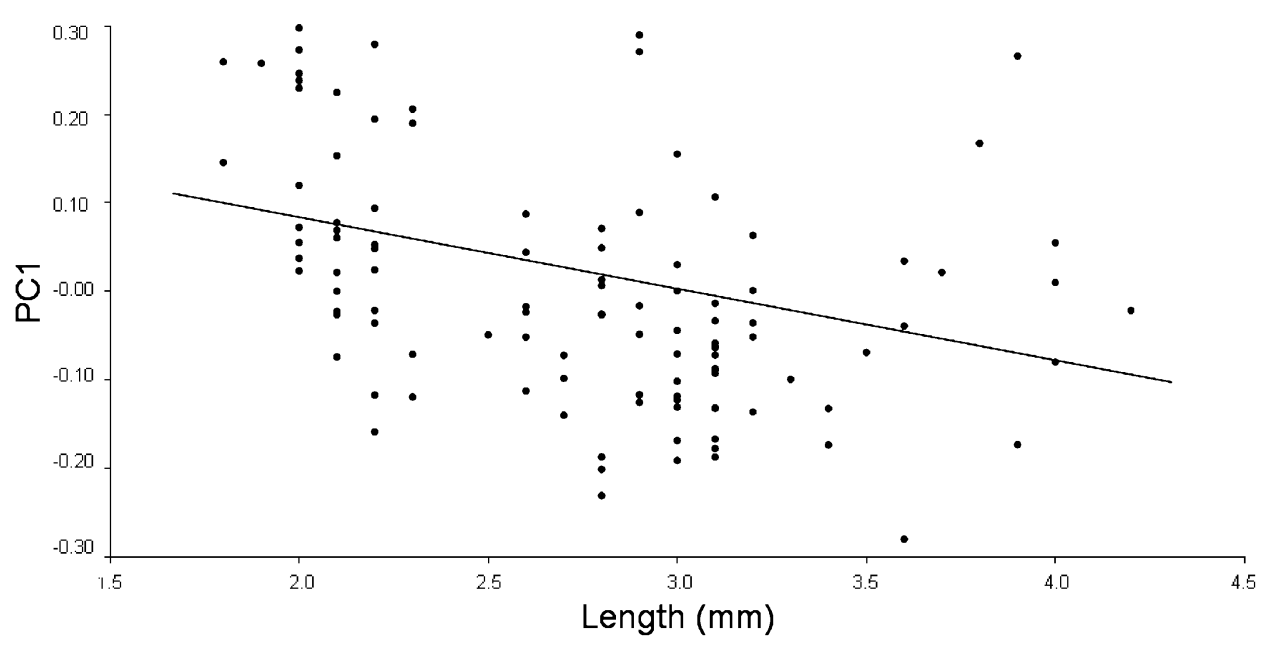

Fig. 5. Regression of the Principal Component 1 (PC1) of Procrustes shape coordinates of the third epimeral plate against the size for 109 specimens of Bathyporeia guilliamsoniana (Spence Bate, 1857) $\left(r^{2}=0.342 ; p<0.001\right)$.

The variation and the correlation with body length observed were obtained from a dataset mainly constituted by females, although d'Udekem d'Acoz \& Vader (2005: p. 18) described females "always with tooth", without remarking the degree of variation. Furthermore, d'Udekem d'Acoz \& Vader (2005) also noted that some males could be toothless but with an angular discontinuity, an outline here attributable to shape II (fig. 4B) which was equally distributed in males and females.

The geometric morphometric study shows clearly the variance of shapes within the character (see fig. 4B) and does not separate clusters of shapes, showing a pattern of continuous variation.

The use of geometric morphometrics and the thin-plate spline method may serve to complement descriptions and aid in identification of species. Riedlecker et al. (2008) used the shape of the second gnathopod to assess the intra-specific variation within Caprella mutica Schurin, 1935 and to distinguish this non-native species from the native C. alaskana Mayer, 1903 and C. kennerlyi Stimpson, 1864. Kurdziel \& Knowles (2002) studied the morphological changes in size and shape in response to environmental selective pressures in Jassa marmorata (Holmes, 1903). Amphipods are particularly appropriate for the geometric study of the anatomical shapes.

Demaerel et al. (2008), using molecular markers to study the Atlantic populations of B. guilliamsoniana, reported very high intraspecific diversity and the presence of two distinct $B$. guilliamsoniana groups, possibly cryptic species. These too may profit from geometric morphometric analysis. 


\section{REFERENCES}

AdAms, D. C., F. J. RohlF \& D. E. Slice, 2004. Geometric morphometrics: ten years of progress following the 'revolution'. Italian Journal of Zoology, 71: 5-16.

Bellan-Santini, D., 1989. Genus Bathyporeia. In: S. Ruffo (ed.), The Amphipoda of the Mediterranean, 2, Gammaridea (Haustoriidae to Lysianassidae). Mémoires de l'institut Océanographique, Monaco, 13: 365-380.

Bookstein, F. L., 1989. Principal warps: thin-plate splines and the decomposition of deformations. The IEEE Transactions on Pattern Analysis and Machine Intelligence, 11: 567-585.

—, 1991. Morphometric tools for landmark data: geometry and biology. (Cambridge University Press, Cambridge).

- - 1996. Combining the tools of geometric morphometrics. NATO ASI Series, Series A: Life Science, 284: 131-151.

— _ 1997. Landmark methods for forms without landmarks: localizing group differences in outline shape. Medical Image Analysis, 1: 225-243.

Bookstein, F. L., A. P. Streissguth, P. D. Sampon, P. D. Connor \& H. M. Barr, 2002. Corpus callosum shape hypervariation covaries with neuropsychological deficits in adult males with heavy fetal alcohol exposure. Neuroimage, 15: 233-251.

Borja, A., J. Franco \& V. A. Perez, 2000. Marine Biotic Index to establish the ecological quality of soft-bottom benthos within European estuarine and coastal environments. Marine Pollution Bulletin, 40: 1100-1114.

CONLAN, K. E., 1990. Revision of the crustacean amphipod genus Jassa Leach (Corophioidea: Ischyroceridae). Canadian Journal of Zoology, 68: 2031-2075.

Costa, F. O., C. M. Henzler, D. H. Lunt, N. M. Whiteley \& J. Rock, 2009. Probing marine Gammarus (Amphipoda) taxonomy with DNA barcodes. Systematics and Biodiversity, 7: 365 379.

Deidun, A., F. Marrone, I. Sparacio, M. Arculeo, T. Curatolo, A. Sciberras, J. SCIBERRAS \& S. Lo BRUTTO, 2011. Morphological variability in and distributional data on Phaleria bimaculata populations from islands of the Central Mediterranean area. Bulletin of Insectology, 64: 215-222.

Demaerel, V., S. Degraer, M. Vincx \& T. Remerie, 2008. Research into the distribution of the genus Bathyporeia (Crustacea, Amphipoda) by means of molecular markers. In: J. MEES ET AL. (eds.), VLIZ Young Scientists' Day, Brugge, Belgium, 29 February 2008: book of abstracts. VLIZ Special Publication, 40: 2-3.

KLINGENBERG, C. P., 2011. MORPHOJ: an integrated software package for geometric morphometrics. Molecular Ecology Resources, 11: 353-357.

Kurdziel, J. P. \& L. L. KnOwles, 2002. The mechanisms of morph determination in the amphipod Jassa: implications for the evolution of alternative male phenotypes. Proceedings of the Royal Society of London Series B: Biological Sciences, 269: 1749-1754.

Riedlecker, E., G. V. Ashton \& G. M. Ruiz, 2008. Geometric morphometric analysis discriminates native and non-native species of Caprellidae in western North America. Journal of the Marine Biological Association of the United Kingdom, 89: 535-542.

RohlF, F. J., 1993. Relative warps analysis and an example of its application to Mosquito wings. In: L. F. Marcus, E. Bello \& A. Garcia-VAldecasas (eds.), Contributions to morphometrics, Monografias del Museo National de Ciencias Naturales, Madrid: 132-159.

— — 1996. Morphometric spaces, shape components and the effects of linear transformations. NATO ASI Series, Series A: Life Science, 284: 117-129.

— - 2004. tpsDIG 2 software, available online at http://life.bio.sunysb.edu/morph/.

— - 2005. tpsRegr thin-plate spline regression, version 1.31. Department of Ecology and Evolution, State University of New York, Stony Brook, NY.

— - 2008. tpsUtil 1.45 software, available online at http://life.bio.sunysb.edu/morph/. 
Rohlf, F. J. \& D. SLICE, 1990. Estensioni del metodo di Procuste per la sovrapposizione ottimale dei punti di riferimento. Zoologia Sistematica, 39: 40-59.

SAMPson, P. D., F. L. Bookstein, F. H. SheEhAn \& E. L. Bolson, 1996. Eigenshape analysis of left ventricular outlines from contrast ventriculograms. NATO ASI Series, Series A: Life Science, 284: 211-233.

SheETs, H. D., 2003. MakeFan6 software, IMP software series, available online at http://www. canisius.edu/sheets/morphsoft.html/.

SheEts, H. D., K. KIM \& C. E. Mitchell, 2004. A combined landmark and outline-based approach to ontogenetic shape change in the Ordovician trilobite Triarthrus becki. In: A. M. T. ELEWA (ed.), Morphometrics: applications in biology and paleontology: 67-82. (Springer, New York, NY).

Sirna Terranova, M., S. Lo Brutto, M. Arculeo \& J. B. Mitton, 2007. A mitochondrial phylogeography of Brachidontes variabilis (Bivalvia: Mytilidae) reveals three cryptic species. Journal of Zoological Systematics and Evolutionary Research, 45: 289-298.

D'Udekem D'ACOZ, C., 2004. The genus Bathyporeia Lindström, 1855, in western Europe (Crustacea: Amphipoda: Pontoporeiidae). Zoologische Verhandelingen, 348: 3-162.

_ _ 2011. Validation of the family Bathyporeiidae (Crustacea, Amphipoda). Zootaxa, 2791: 5462.

D'Udekem D'Acoz, C., H. M. Chams Echchaoui \& M. Menioui, 2005. Further observations on North African and South Iberian Bathyporeia (Crustacea, Amphipoda), with the description of a new species. Contributions to Zoology, 74: 279-300.

D'UdeKem D'ACOZ, C. \& W. VAdER, 2005. The Mediterranean Bathyporeia revisited (Crustacea, Amphipoda, Pontoporeiidae), with the description of a new species. Bollettino del Museo Civico di Storia Naturale di Verona, 29: 3-38.

VADER, W. \& T. KRAPP-SCHICKEL, 2012. On some maerid and melitid material (Crustacea: Amphipoda) collected by the Hourglass Cruises (Florida). Part 2: genera Dulichiella and Elasmopus, with a key to world Elasmopus. Journal of Natural History, 46: 1179-1218.

VIscosi, V. \& A. CARDINI, 2011. Leaves, taxonomy and geometric morphometrics: a simplified protocol for beginners. PLoS ONE, 6: e25630.

Zelditch, M., D. Swiderski, H. D. SheEts \& W. FinK, 2004. Geometric morphometrics for biologists: a primer. (Elsevier, London).

First received 18 February 2012.

Final version accepted 25 May 2012. 